Joanna Paprzycka

Uniwersytet Łódzki

joanna.paprzycka@edu.uni.lodz.pl

\title{
Opinie przedstawicieli lódzkiej branży turystycznej na temat głównych turystycznych aktów prawnych
}

\section{Streszczenie}

Celem pracy jest przedstawienie analizy opinii pracowników łódzkiej branży turystycznej na temat głównych turystycznych aktów prawnych, ze szczególnym odniesieniem do zmian dokonanych w ostatnich kilku latach w prawie branżowym. Metody badawcze zastosowane w opracowaniu to wywiad standaryzowany pogłębiony oraz obserwacja uczestnicząca. W badaniu zwrócono uwagę m.in. na ocenę dokonanych zmian oraz potrzebę dalszych uregulowań prawnych, nieprecyzyjność terminologiczną najważniejszych aktów prawnych, wciąż nierozwiązany w branży turystycznej problem „szarej strefy” czy ocenę respondentów funkcjonowania Turystycznego Funduszu Gwarancyjnego. W wyniku przedstawionej analizy autorka dostrzega duże rozbieżności w postrzeganiu głównych turystycznych aktów prawnych, modyfikowanych w ciągu ostatnich kilku lat.

\section{Wprowadzenie}

Prawo turystyczne w ostatnich kilku latach poddane zostało gruntownej zmianie. Uznano, że treści przedstawiane przez turystyczne akty prawne obowiązujące od 1997 r. z upływem czasu uległy dezaktualizacji względem rozwijającego się rynku usług turystycznych. Ewolucja tych treści miała na celu m.in. usprawnienie pracy branży turystycznej, zwłaszcza touroperatorów, zwiększenie klarowności, usprawnienie obsługi klienta i zwiększenie jego bezpieczeństwa. Dokonane zmiany prawne mają duży wpływ na działalność przedsiębiorstw, jednak wzbudzają też wiele kontrowersji. Celem opracowania jest identyfikacja i przedstawienie analizy opinii pracowników łódzkiej branży turystycznej na temat głównych

Cytowanie: Paprzycka J. (2021). Opinie przedstawicieli łódzkiej branży turystycznej na temat głównych turystycznych aktów prawnych. W: K. Borodako (red.), Turystyka w okresie pandemii. Bogucki Wydawnictwo Naukowe, Poznań-Kraków, s. 153-163. https://doi.org/10.12657/9788379863501-15 
turystycznych aktów prawnych, ze szczególnym odniesieniem do zmian dokonanych w ostatnich kilku latach w prawie branżowym. Badani stanowią grupę głównych użytkowników wymienionego prawa, których opinie wydają się niekiedy pomijane, wraz z ewolucją aktów prawnych. Dla potrzeb niniejszego opracowania wykorzystano formy badań pierwotnych. Badania opinii autorka pracy wykonała przy zastosowaniu wywiadu standaryzowanego pogłębionego oraz obserwacji uczestniczącej.

W poniższym rozdziale autorka zwróciła uwagę na główne akty prawne regulujące funkcjonowanie branży turystycznej, charakterystykę badań oraz najważniejsze wnioski płynące $z$ zebranych opinii. Kluczową rolę odgrywają ustawy i rozporządzenia dotyczące branży turystycznej oraz relacji przedsiębiorstwoklient, m.in. ustawa o imprezach turystycznych i powiązanych usługach turystycznych (Dz.U. 2017 poz. 2361) wraz z aktami wykonawczymi do ustawy, a także ustawa o usługach hotelarskich oraz usługach pilotów wycieczek i przewodników turystycznych (Dz.U. 1997 nr 133 poz. 884). Przytoczone akty prawne były dla autorki podstawą przygotowania głównego narzędzia badawczego oraz przeprowadzenia badań, stanowiły również fundament całego opracowania. Autorka wzbogaciła swoją wiedzę o treści zawarte $\mathrm{w}$ informatorze wydanym przez Ministerstwo Sportu i Turystyki na temat ustawy o imprezach turystycznych i powiązanych usługach turystycznych, prezentującą treści ustawy budzące wątpliwości z perspektywy autorów ustawy, główne cele i założenia dokonanych zmian prawnych oraz uzasadnienie zmian. Jako że nie minęło wiele czasu od opublikowania zmodyfikowanych aktów prawnych, autorce opracowania nie udało się dotrzeć do podobnych badań prowadzonych $\mathrm{w}$ odniesieniu do wyżej wymienionych aktów prawnych.

\section{Przegląd literatury}

Jak wskazują Cybula i Raciborski (2008), prawo związane z branżą turystyczną przez wiele lat było marginalizowane w przestrzeni legislacyjnej. Fakt ten można wiązać z ograniczeniem dostępu do usług turystycznych i brakiem ich komercjalizacji. Wraz z przemianami gospodarczymi i wzmożeniem zainteresowania turystyką pojawiły się zagrożenia dla interesów uczestników turystyki. Za okres przełomowy dla branżowych kwestii prawnych uznać można ostatnią dekadę XX w. Wtedy właśnie, w oparciu o prawo Unii Europejskiej, w celu eliminacji wspomnianych zagrożeń stworzona została ustawa o usługach turystycznych z dnia 29 sierpnia $1997 \mathrm{r}$. Był to pierwszy branżowy akt prawny, kompleksowo omawiający funkcjonowanie przedsiębiorstw turystycznych. Zagadnienie owej ustawy $\mathrm{i}$ jej powiązań z innymi krajowymi oraz międzynarodowymi aktami prawnymi omawia Gospodarek (2006). Kwestie te z punktu widzenia prawniczego w kolejnych publikacjach przybliżają także m.in. Cybula oraz Raciborski (2008).

Wraz ze zmianami prawnymi dokonanymi w drugiej dekadzie XXI w. pojawiły się kolejne kontrowersje dotyczące prawa turystycznego. Część z nich odnaleźć można w publikacji Ministerstwa Sportu i Turystyki (2018). Opracowanie zawiera 
rozważania nad kwestiami spornymi w branży turystycznej, a także proponowane rozumienie tych treści przez przedstawicieli MSiT. Kwestie sporne dotyczą treści m.in. terminologii użytej w ustawie, funkcjonowania przedsiębiorstw turystycznych, odpowiedzialności prawnej podmiotów oraz obszaru dla funkcjonowania tzw. szarej strefy, zawartych w ustawie o imprezach turystycznych i powiązanych usługach turystycznych.

\section{Charakterystyka podziału regulacji prawnych}

Dla uporządkowania zagadnień związanych z prawem turystycznym, a w szczególności z jego rodzajami, autorka opracowała schemat obrazujący opisywane zagadnienie. Jako pierwszy etap podziału autorka wyodrębniła dwa rodzaje prawa wykorzystywanego w branży turystycznej, po uwzględnieniu jego pierwotnego przeznaczenia wobec turystyki (ryc. 1).

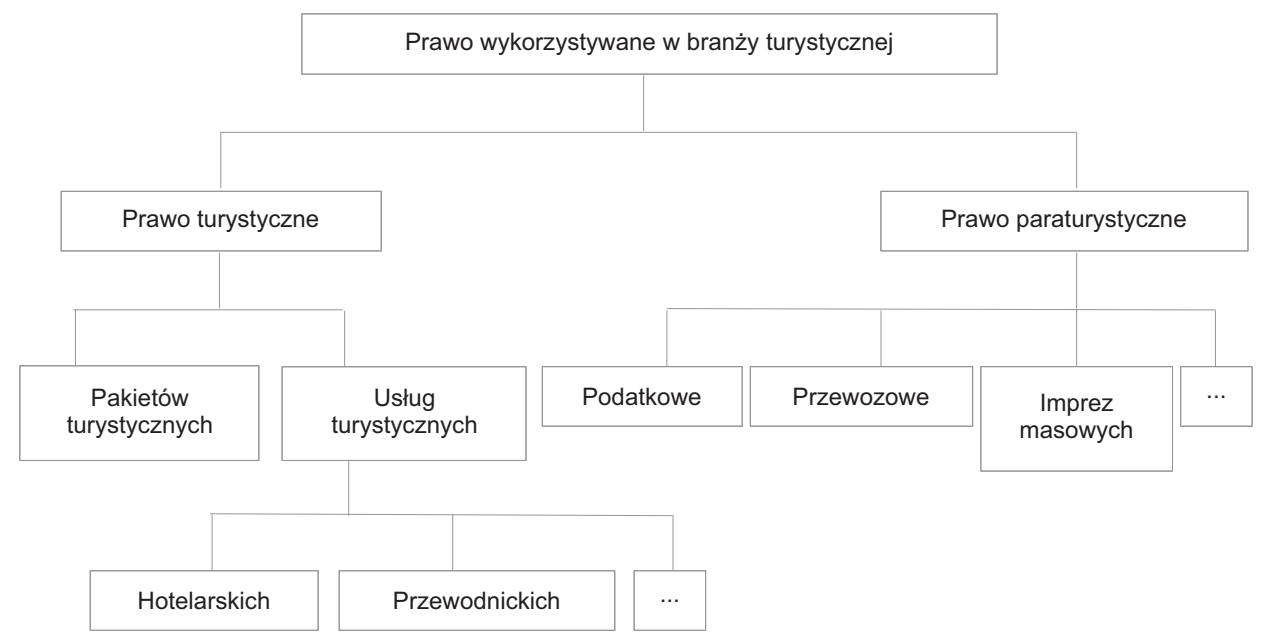

Ryc. 1. Schemat obrazujący prawo wykorzystywane w branży turystycznej

Źródło: opracowanie własne.

Pierwszy rodzaj prawa stanowi stricte prawo turystyczne, które należy rozumieć jako wszelkie akty prawne powstałe w celu regulacji aktywności związanych z działalnością turystyczną. Autorka zaproponowała dalszy podział prawa turystycznego na regulacje dotyczące pakietów turystycznych oraz poszczególnych usług turystycznych. Miano pakietów turystycznych obejmuje m.in. imprezy turystyczne, tj. połączenie minimum dwóch usług, objętych wspólną ceną i programem. Regulacje odnoszące się do usług turystycznych to m.in. wytyczne w dziedzinie świadczenia usług w obiektach hotelarskich, świadczenia usług przewodnickich i inne. Drugim rodzajem prawa wyodrębnionego przez autorkę opracowania jest tzw. „prawo paraturystyczne”. Termin ten określa rodzaj prawa, które przygotowane zostało na potrzeby innych branż, dziedzin życia oraz społeczności 
niezwiązanych z turystyką, jednak pośrednio lub bezpośrednio dotyczy turystów, przedsiębiorców oraz usługodawców turystycznych. Przykładami takich regulacji mogą być akty prawne w zakresie prawa podatkowego, przewozowego, imprez masowych i inne. Określenie to nie obowiązuje obecnie w literaturze przedmiotu i stanowi propozycję autorki dla podjęcia dalszych rozważań terminologicznych.

\section{Metodyka badań}

Spośród ogólnie dostępnych metod badawczych autorka wybrała następujące metody do zbadania zjawiska opinii publicznej na temat prawa turystycznego w gronie przedstawicieli branży: wywiad standaryzowany pogłębiony oraz obserwację. Według autorki metody te są najbardziej miarodajne dla zagadnienia dotyczącego opinii na temat prawa turystycznego, ponieważ pozwalają na największą swobodę wypowiedzi. Co za tym idzie, opinia respondenta jest wyrazem subiektywnego poglądu, wyrobionego na podstawie aktów prawnych oraz doświadczenia zawodowego ankietowanego. Jak opisuje Apanowicz (2002), wywiad polega na pozyskiwaniu danych $w$ bezpośredniej rozmowie. Obserwacja natomiast stanowi według Apanowicza postrzeganie jednostkowych faktów, zjawisk i osób w wyznaczonym miejscu i czasie. Przedmiot obserwacji w badaniach naukowych stanowić może wszystko, co jest możliwe i dostępne zmysłom obserwatora.

Narzędziem przeprowadzenia wywiadów był kwestionariusz wywiadu. Jest to główne narzędzie badawcze opracowane przez autorkę, składające się z wprowadzenia oraz z pytań podzielonych na trzy części, w zależności od tematyki i stopnia szczegółowości: pierwszej - ogólnej, drugiej - dotyczącej treści ustawy o imprezach turystycznych i powiązanych usługach turystycznych oraz trzeciej przeznaczonej do zebrania opinii od przedstawicieli biur podróży.

Metoda obserwacyjna wdrożona została w formie obserwacji uczestniczącej, narzędziem badawczym był arkusz na własne uwagi, stworzony i zastosowany przez autorkę. Obserwacji podlegali respondenci badań ankietowych podczas bezpośredniej rozmowy $\mathrm{z}$ autorka, $\mathrm{w}$ trakcie oraz po przeprowadzeniu wywiadu. Dotyczyła ona zależności w przekazie werbalnym oraz niewerbalnym uczestników badania. Przekaz ten prowadził do różnych wniosków. Obserwacja miała charakter jawny. Oznacza to, że jej uczestnicy wiedzieli o udziale w badaniu.

Analiza materiałów źródłowych dokonana została poprzez porównanie treści nowelizowanych ustaw oraz komentarzy pracowników branży, w tym specjalistów w dziedzinie prawa turystycznego. W celu przeprowadzenia analizy wywiadów autorka wykonała zestawienie odpowiedzi respondentów w programie Microsoft Excel, które kolejno zostały porównane do całości opinii uzyskanych $\mathrm{w}$ wyniku badań. Obserwacja była uzupełnieniem informacji uzyskanych $\mathrm{w}$ trakcie wywiadu. Karta obserwacji dołączona została do właściwego kwestionariusza wywiadu i stanowiła obszar analizy w odniesieniu do odpowiedzi konkretnego respondenta.

Przy dobraniu, skonstruowaniu i zastosowaniu właściwych narzędzi badawczych autorka korzystała z publikacji Apanowicz (2002). Słownik językowy 
Drabik i in. (2006) posłużył do wyjaśnienia kluczowych definicji, zarówno dla przeprowadzenia badań, jak i poddania ich wyników dalszej analizie.

O udział w badaniu poproszono łącznie około 280 osób. Autorka odwiedziła w sumie 36 instytucji zlokalizowanych na terenie Łodzi. Do odwiedzonych placówek należały m.in. biura podróży, stowarzyszenia i organizacje zajmujące się turystyką na terenie miasta, województwa oraz o zasięgu ogólnokrajowym. W efekcie autorce udało się przeprowadzić wywiad z 50 reprezentantami branży turystycznej. Byli to przedstawiciele obu płci, zajmujący się zawodowo turystyką (pracownicy biur podróży, piloci, przewodnicy), prawem turystycznym oraz pokrewnymi profesjami (specjaliści ds. turystyki w organizacjach lokalnych). Wśród 50 respondentów było 26 mężczyzn oraz 24 kobiety, zajmowali oni różne stanowiska pracy (zwykłe lub kierownicze), mieli różne wykształcenie czy staż pracy. Profil respondentów był zróżnicowany, co dało szansę poznania opinii możliwie najbardziej miarodajnej i bezstronnej. Na możliwość udziału w badaniu decydujący wpływ miała kompleksowa znajomość aktów prawnych regulujących działalność branży turystycznej.

\section{Wyniki badań}

Na początku badania ankietowani zostali zapytani o ocenę regulacji prawnych dokonanych $\mathrm{w}$ ciągu ostatnich lat w głównych turystycznych aktach prawnych, tj. m.in. ustawie o usługach hotelarskich oraz usługach pilotów wycieczek i przewodników turystycznych (1997), ustawie o imprezach turystycznych i powiązanych usługach turystycznych (2017) oraz w powiązanych aktach prawnych (ryc. 2).

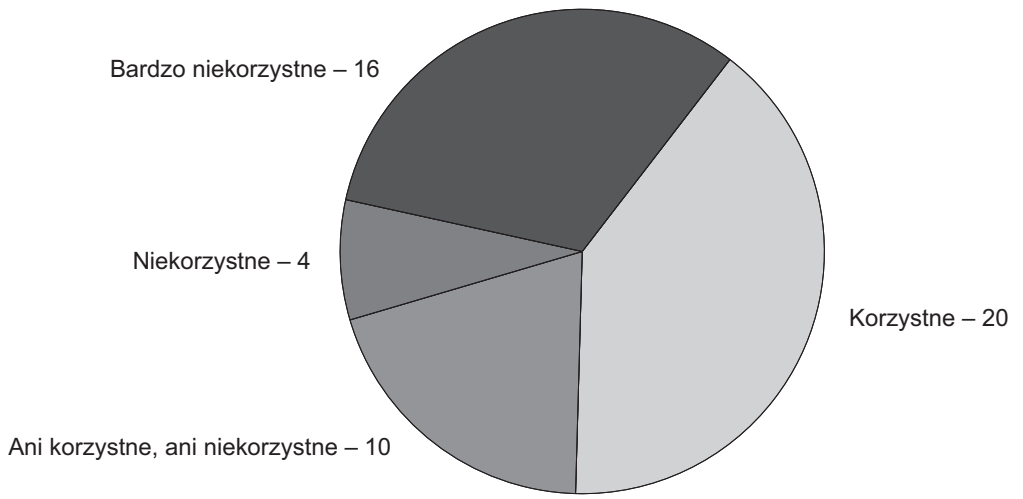

Ryc. 2. Ocena uregulowań prawnych z ostatnich lat Źródło: opracowanie własne.

Jak pokazuje analiza opinii, nikt z ankietowanych nie wskazał wysokich korzyści ze zmian prawnych. Po 20 osób wskazało, że zmiany były korzystne oraz niekorzystne w różnym stopniu. Wydaje się to o tyle niepokojące, że negatywny wpływ uregulowań podkreślały głównie osoby o najdłuższym stażu zawodowym. 
Doświadczenie tych osób świadczyć może o bardziej zaawansowanym stanie wiedzy i skali porównawczej na przestrzeni lat.

Kolejną kluczową kwestią poruszoną podczas wywiadu były niedogodności wynikające ze zmian prawnych względem przedsiębiorców. Ankietowani zostali zapytani, czy takowe zauważają. 33 z 50 osób przyznało, że widzi niedogodności będące rezultatem zmian $w$ prawie turystycznym. W efekcie poproszono o doprecyzowanie, o jakie niedogodności głównie chodzi. Respondenci mogli wskazać więcej niż jedną propozycję oraz rozwinąc ją o własne uwagi (ryc. 3).

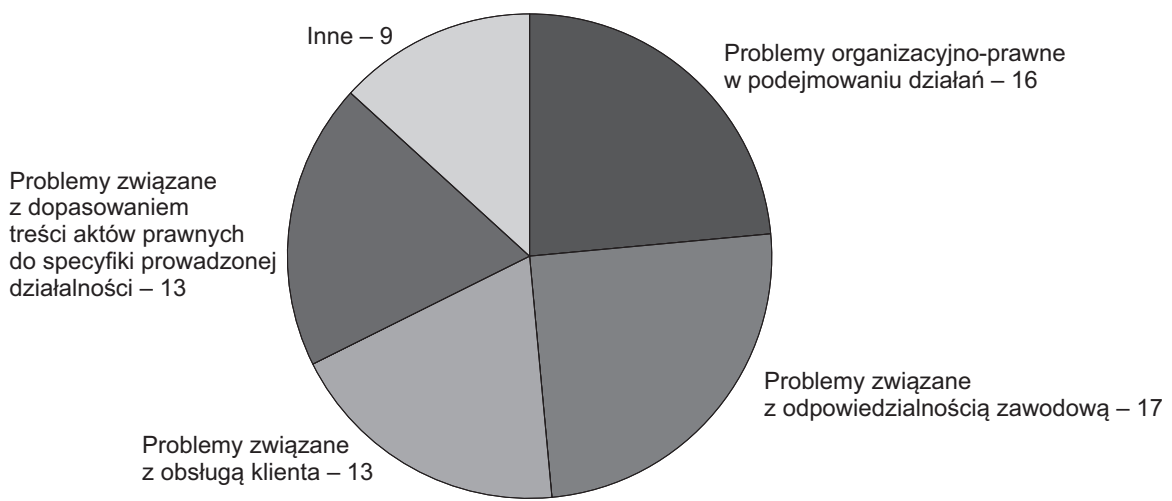

Ryc. 3. Opinie na temat niedogodności wynikających ze zmian prawnych Źródło: opracowanie własne.

Zdania przedstawicieli łódzkiej branży turystycznej były bardzo podzielone. Najwięcej osób wskazało, że w związku ze zmianami powiększyły się problemy $z$ odpowiedzialnością zawodową. W ramach pogłębienia tematyki badani wiązali niedogodności $\mathrm{w}$ tym zakresie szczególnie z „uwolnieniem” zawodu pilota i przewodnika turystycznego. Drugą najczęściej wskazywaną odpowiedzią okazały się problemy organizacyjno-prawne, zwłaszcza nadmierna ilość dokumentów biurowych, które muszą zostać wypełnione. W ramach pogłębienia problematyki respondenci wyrażali opinię o tzw. „nadmiarze biurokracji”. Ich zdaniem wypełnianie dokumentów często ma miejsce kosztem czasu, który można byłoby poświęcić interesariuszowi. Wskazywali oni potrzebę ograniczenia liczby wymaganych dokumentów wraz z kolejnymi zmianami prawa turystycznego, co miałoby wpłynąć na jakość obsługi klienta. Najrzadziej wybieraną odpowiedzią była „inne”, jednak osoby wybierające tę opcję i proszone o doprecyzowanie zwracały uwagę na działalność tzw. „szarej strefy”. Jak sugerują Drabik i in. (2006), „szara strefa" oznacza niezarejestrowaną lub niezgodną z obowiązującymi przepisami działalność gospodarczą, a także osoby i firmy prowadzące taką działalność. W treści rozdziału pojęcie „szarej strefy” powinno być również rozumiane jako działalność funkcjonująca na podstawie niedoprecyzowania przepisów prawnych.

Ankieterka zapytała respondentów, czy zauważają potrzebę dalszych zmian w prawie turystycznym. Większość osób (36 z 50) uznała, że istnieje taka potrzeba. Osoby te zostały poproszone o wskazanie głównych potrzeb względem 
dalszych zmian w prawie turystycznym, z możliwością wyboru więcej niż jednej odpowiedzi (ryc. 4).

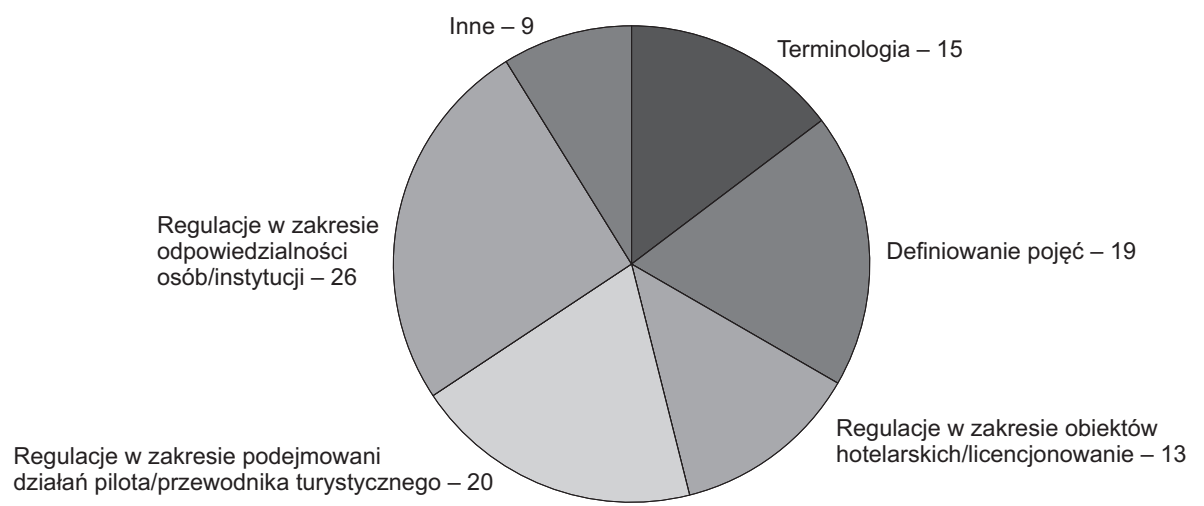

Ryc. 4. Charakterystyka potrzeb dalszych zmian prawnych

Źródło: opracowanie własne.

W opinii respondentów zdecydowanie niezbędne są zmiany dotyczące odpowiedzialności osób i instytucji, co wskazała ponad połowa ankietowanych, a także regulacje związane $z$ podejmowaniem aktywności i licencjonowaniem pilotów oraz przewodników turystycznych. Wiele osób zauważyło potrzebę udoskonalenia $\mathrm{w}$ zakresie terminologii i definiowania pojęć. Zapytano też o to, w których aktach prawnych najbardziej potrzebne są takie zmiany. Największą konieczność zmian wskazano w ustawie o imprezach turystycznych i powiązanych usługach turystycznych (2017). Ten akt prawny, jako obszar konieczny do zmiany, wskazało 35 spośród 50 osób. 2/5 badanej grupy podkreśliło potrzebę zmian w ustawie o usługach hotelarskich oraz usługach pilotów wycieczek i przewodników turystycznych (1997).

Druga i trzecia część pytań skupiała się na uszczegółowieniu opinii dotyczących treści objętych ustawą o imprezach turystycznych i powiązanych usługach turystycznych (2017). Ponad połowa ankietowanych wskazała, że ustawa jest nieprzydatna lub mało przydatna ze względu na niedoprecyzowanie przepisów. Jak wykazało pogłębienie problematyki wywiadu $\mathrm{w}$ tych częściach, najbardziej kłopotliwe jest niedoprecyzowanie treści ustawy i zawartych w niej definicji. Stwarza to niekiedy możliwość swobodnej interpretacji przepisów, co prowadzi do podejmowania działań poza prawem. Mniej więcej połowa ankietowanych wskazała potrzebę dokładniejszej regulacji odpowiedzialności podmiotów organizujących imprezy i powiązane usługi turystyczne oraz jednostek zajmujących się ich sprzedażą. Średnio co drugi respondent akcentował potrzebę doprecyzowania wymagań stawianych organizatorom imprez turystycznych. Jak wykazały badania pogłębione, wymagania te mają w opinii respondentów znaczący wpływ na ewentualną możliwość rozwoju tzw. „szarej strefy”.

W kolejnym pytaniu autorka chciała się dowiedzieć, czy wraz z dokonaniem zmian prawnych możliwość dla działania szarej strefy została zlikwidowana lub ograniczona (ryc. 5). 


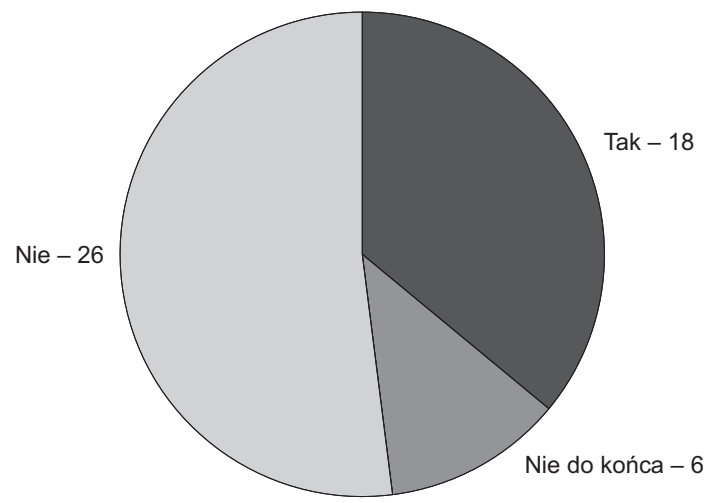

Ryc. 5. Ocena likwidacji możliwości funkcjonowania „szarej strefy” Źródło: opracowanie własne.

Jak wskazuje analiza opinii, ponad połowa osób uważa, że wątpliwości związane $z$ działaniem "szarej strefy” nie do końca zostały zlikwidowane lub kategorycznie nie zostały zlikwidowane. Dalszą możliwość dla działania „szarej strefy” wskazały głównie osoby o najdłuższym stażu pracy. 9 z 50 badanych osób w ramach pogłębienia tematyki „szarej strefy” uzupełniło swoją opinię o ocenę, że możliwość jej funkcjonowania została poszerzona wraz ze zmianami prawnymi.

Ostatnim pytaniem w trakcie wywiadu było pytanie o działalność Turystycznego Funduszu Gwarancyjnego. Adresowane było ono głównie do osób stanowiących przedstawicielstwo biur podróży, jednak zdecydowali się odpowiedzieć na nie również niektórzy przewodnicy, regularnie współpracujący z touroperatorami. Ankietowani zostali poproszeni o ocenę przejrzystości zasad funkcjonowania rachunku. Aż 32 osoby wskazały, że zasady funkcjonowania funduszu są jasne i obecnie nie wymagają dalszych modyfikacji (ryc. 6).

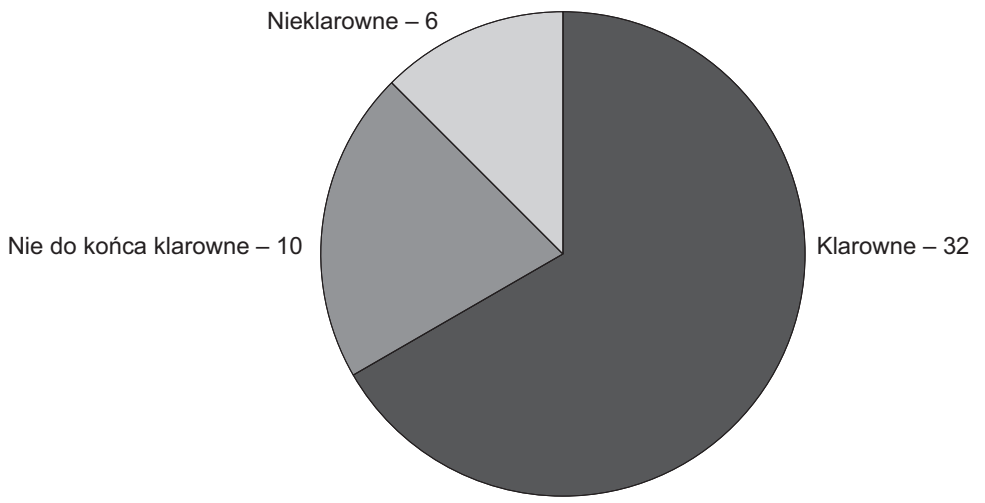

Ryc. 6. Ocena klarowności funkcjonowania TFG

Źródło: opracowanie własne.

W ramach uzupełnienia zagadnienia Turystycznego Funduszu Gwarancyjnego ankieterka zapytała, czy respondenci uważają wysokość gwarancji za adekwatną do zakresu działalności. Ponad połowa ankietowanych uznała, że stawki są 
adekwatne, jednak 20 osób wskazało na rozbieżności w ich wysokości. W pogłębionym wywiadzie osoby te wyraziły opinie, że stawki są zawyżane dla małych przedsiębiorstw, a zaniżane dla dużych touroperatorów.

Obserwacje własne autorki pozwoliły zauważyć wybiórczą znajomość prawa turystycznego poszczególnych grup zawodowych, niekiedy ukrywaną, zwłaszcza przez osoby zajmujące stanowiska wyższego szczebla, głównie kierownicze. Badania pokazały, że większość przedsiębiorstw zatrudnia pracownika zewnętrznego, wyspecjalizowanego w zakresie prawa turystycznego. Metoda obserwacji umożliwiła autorce wyciągnięcie wniosków, że najbardziej kompleksową wiedzę teoretyczną z zakresu prawa turystycznego posiadali pracownicy przedsiębiorstw turystycznych, będący jednocześnie przedstawicielami placówek oświatowych, natomiast największą wiedzą praktyczną z zakresu funkcjonowania przedsiębiorstw turystycznych dysponowali piloci i przewodnicy turystyczni. Większość przedstawicieli ostatniej wspomnianej grupy zawodowej przed rozpoczęciem badania wyraziła obawę o swoją niską lub wybiórczą znajomość prawa branżowego. W rzeczywistości stanowili oni najbardziej rzetelne źródło opinii na temat prawa turystycznego. W trakcie badania najbardziej okrojone opinie oraz brak znajomości niektórych treści wykazali przedstawiciele organizacji i stowarzyszeń turystycznych (instytucji społecznych).

Największą trudnością w czasie badań okazał się fakt, że z grona 280 osób $z$ łódzkiej branży turystycznej, udało się przeprowadzić jedynie 50 wywiadów. Jak wskazała znaczna część podmiotów poproszonych o udział w badaniu, taki stan rzeczy wiąże się z wybiórczą znajomością prawa turystycznego lub niekiedy jej brakiem wśród potencjalnych respondentów. Wielu pracowników turystycznych zna jedynie fragmenty ustawy lub innych branżowych aktów prawnych. Dla przykładu znaczna część łódzkich pilotów i przewodników turystycznych przyznaje, że koncentruje się głównie na znajomości ustawy o usługach hotelarskich oraz usługach pilotów wycieczek i przewodników turystycznych (1997). Głównymi, choć oczywiście nie jedynymi użytkownikami i zarazem „znawcami” ustawy o imprezach turystycznych i powiązanych usługach turystycznych (2017) są pracownicy biur podróży oraz osoby o wykształceniu turystycznym, pracujące w edukacji i nauczające treści ustaw.

\section{Zakończenie}

Zgodnie $\mathrm{z}$ celem opracowania w rozdziale zidentyfikowano i przedstawiono analizę opinii pracowników branży turystycznej na temat głównych turystycznych aktów prawnych. $Z$ badań wynika, że podmioty objęte ankietą mają bardzo rozbieżne opinie na temat nowelizacji prawa turystycznego dokonanego w Polsce w ostatnich latach, jednak opinie te są coraz bardziej krytyczne względem kolejnych aktów prawnych. Niezmiennie wskazywane są potrzeby dalszego udoskonalania głównych krajowych aktów prawnych na rzecz turystyki. Do obszarów stwarzających największe problemy branżowe zaliczane jest przyzwolenie na działalność tzw. „szarej strefy”, co może skutkować zwiększeniem jej zasięgu na rynku turystycznym. 
Podsumowując wyniki badań ankietowych, należy stwierdzić, że ponad połowa respondentów z branży turystycznej uważa, iż konieczne są dalsze zmiany $\mathrm{w}$ prawie turystycznym. Główne problemy wynikają z niedoprecyzowania w zakresie odpowiedzialności osób i instytucji, a także podejmowania aktywności i licencjonowania pilotów oraz przewodników turystycznych. W opinii podmiotów objętych badaniem wraz z kolejnymi zmianami prawnymi ograniczona powinna zostać liczba dokumentów wymaganych w ramach działalności biur podróży, co miałoby znaczący wpływ na obsługę klientów. Wielu badanych zauważyło potrzebę udoskonalenia treści i sformułowań użytych w ustawach. Najczęściej wskazywanym dokumentem, w którym dalsze zmiany są niezbędne, jest ustawa o imprezach turystycznych i powiązanych usługach turystycznych (2017). Ustawa ta wymaga doprecyzowania w zakresie terminologicznym i definiowania pojęć w niej zawartych. Turystyczny Fundusz Gwarancyjny i zasady jego działania wydają się dość jasne w funkcjonowaniu, wątpliwości budzą stawki ustalane dla biur podróży. Według części opinii są one zaniżane dla dużych touroperatorów, natomiast zawyżane dla małych.

Wiedza podmiotów objętych badaniem na temat turystycznych aktów prawnych okazała się bardzo zróżnicowana. Wbrew powszechnie panującej opinii najbardziej kompleksową wiedzą praktyczną o prawie turystycznym wykazali się przewodnicy turystyczni i piloci wycieczek z lódzkiego środowiska branżowego. Najwyższym stopniem wiedzy teoretycznej dysponowali pracownicy jednostek oświatowych, będący jednocześnie przedstawicielami przedsiębiorstw turystycznych.

Autorka powyższego opracowania rekomenduje dalsze badania nad prawem turystycznym $w$ świetle satysfakcji z jego zmian i funkcjonowania jednostek regulowanych przez poszczególne akty prawne. Badanie może opierać się zarówno na opiniach przedsiębiorców, jak i próbie określenia satysfakcji turystów z obsługi oraz ochrony w zakresie m.in. ich bezpieczeństwa ekonomicznego, zdrowia lub powierzonego mienia w imię działalności regulowanej treścią prawa.

\section{Literatura}

Apanowicz J. (2002). Metodologia ogólna. Wydawnictwo WSAiB, Gdynia.

Cybula P., Raciborski J. (2008). Turystyka a prawo. Wyższa Szkoła Turystyki i Ekologii, Kraków.

Drabik L., Kubiak-Sokół A., Sobol E. (2006). Słownik języka polskiego PWN. Wydawnictwo Naukowe PWN, Warszawa.

Gospodarek J. (2006). Prawo turystyczne. Centrum Doradztwa i Informacji Difin, Warszawa.

Ministerstwo Sportu i Turystyki (2018). Ustawa o imprezach turystycznych i powiązanych usługach turystycznych.

Ustawa z dnia 24 listopada 2017 r. o imprezach turystycznych i powiązanych usługach turystycznych (Dz.U. 2017 poz. 2361).

Ustawa z dnia 29 sierpnia 1997 r. o usługach hotelarskich oraz usługach pilotów wycieczek i przewodników turystycznych (Dz.U. 1997 nr 133 poz. 884). 


\section{Łódź tourist industry employees' opinions concerning the main tourist legal acts}

The purpose of this study is to present an analysis of the opinions of employees of the tourism industry in Łódź on the main tourist legal acts, with particular reference to the changes made in the last few years in the tourism law. The research methods used in the study are standardized deepened interview and participant observation. The study is focused on, among others, evaluation of the changes made and the need for further legal changes, imprecision in terminology of the most important legal acts, the still unsolved problem of the gray area in the tourism industry, or the evaluation by the respondents in reference to the functioning of the Tourist Guarantee Fund. As a result of the presented analysis, the author notices large discrepancies in the perception of the main tourist legal acts that have been modified in the last few years.

Translated by Joanna Paprzycka 